\title{
Adultyzm - próba sygnalizacji zjawiska na podstawie badań własnych ${ }^{3}$
}

\begin{abstract}
STRESZCZENIE
Wiek, obok płci, stanowi jedną z głównych cech determinujących pozycję społeczną jednostki. Dyskryminacja ze względu na wiek najczęściej pojawia się w kontekście osób starszych. Problematyka ta jest często podejmowana w dyskursie naukowym i medialnym. Rzadziej dostrzega się problem ageizmu z innej strony - dyskryminacji osób młodych, która w literaturze naukowej funkcjonuje pod nazwą adultyzmu. Najogólniej ujmując, adultyzm to postrzeganie młodych osób w kategoriach niedojrzałości. Percepcja ta nie jest poparta racjonalnymi przesłankami wynikającymi z zachowania dyskryminowanej osoby, a jedynie wynika z wyobrażeń osoby dyskryminującej. Wyobrażenia te polegają na tendencji do uogólniania w oparciu o negatywne doświadczenia z osobami w podobnym wieku i przypisaniu domniemanych cech jako typowych dla całego przedziału wiekowego. Ta forma dyskryminacji obecna jest w instytucjach społecznych, prawie, obyczajach i postawach.

Przeprowadzone badania przebiegały dwuetapowo, łącząc w sobie strategię ilościową (sondaż diagnostyczny z wykorzystaniem ankiety) i jakościową (metoda Photovoice). Celem badań było poznanie obszarów, w obrębie których młodzi ludzi doświadczają dyskryminacji oraz jej form. Grupę
\end{abstract}

1 Dagmara Dobosz, Wydział Pedagogiki i Psychologii, Uniwersytet Śląski w Katowicach, Polska, e-mail: dagmaradobosz@vp.pl, ORCID ID: https://orcid.org/0000-0003-2230-3208.

2 Katarzyna Front-Dziurkowska, Wydział Pedagogiki i Psychologii, Uniwersytet Śląski w Katowicach, Polska, e-mail: katarzyna.front@us.edu.pl, ORCID ID: https://orcid.org/0000-00031078-0349.

3 Projekt „Społeczny i indywidualny obraz adultyzmu” sfinansowany z dotacji dla młodych naukowców 2017. 
badaną stanowiła młodzież w wieku 18-24 lat (100 badanych), dobrana w sposób celowy z terenu województwa śląskiego. Zwieńczeniem projektu badawczego było przygotowanie i poprowadzenie przez osoby w niego zaangażowane warsztatu dotyczącego adultyzmu dla młodzieży. Analiza zebranego materiału empirycznego oraz doświadczenia w pracy nad projektem obnażyły nieświadomość młodych ludzi w kwestii występowania takiej formy dyskryminacji oraz mylenie adultyzmu z innymi jej formami. Niepokojące jest również zjawisko szybkiej internalizacji przez młodzież postaw charakterystycznych dla osób dorosłych względem młodszych od siebie, zataczając tym samym koło w dyskryminacji.

\title{
Słowa kluczowe:
}

adultyzm, dyskryminacja osób młodych, młodzież, wykluczenie

\begin{abstract}
Age, next to gender, is one of the main features determining the social standing of the individual. Discrimination by age most often appears in the context of older people. The discrimination of young people is rarely noticed and in the scientific literature exists under the name of adultism. Broadly speaking, adultism is the perception of young people regarding immaturity. This perception is not supported by the nature of the discriminated person's behaviour but only arises from the viewpoints of those who discriminate. These notions rely on the tendency to generalise by negative experiences with people of similar age and to attribute alleged traits as typical for the entire age bracket. This form of discrimination is present in social institutions, law, customs and attitudes.

The studies were carried out in two stages, combining the quantitative strategy (diagnostic survey using the questionnaire) and qualitative research strategy (Photovoice method). The primary goal of the research was to get to know the areas in which young people experience discrimination and its forms. The study group consisted of young people aged 18-24 (100 respondents), selected in a targeted manner from the area of the Silesian Province. The culmination of the research project was preparing and leading the workshop on adultism for young adults. The analysis of the collected empirical material and experience in work on the project exposed the ignorance of young people about the existence of this type of discrimination and mistaking the adultism with other forms. What is also disturbing is the phenomenon of rapid internalisation by the youth of the attitudes characteristic to adults against younger than themselves, thus coming full circle in discrimination.
\end{abstract}

\section{Keywords:}

adultism, discrimination against young people, youth, exclusion 


\section{WPROWADZENIE}

Problem dyskryminacji jest bardzo często podejmowany w dyskursie naukowym i medialnym ze względu na swą złożoność i wieloaspektowość (Winiarska, Klaus, 2011).

Płeć, wiek, rasa czy klasa społeczna to podstawowe wymiary różnicujące pozycję społeczną jednostki. Początkowo aktywność badawczy skoncentrowana była na kwestii nierówności społecznych wynikających z przynależności klasowej i płci. Dopiero po II wojnie światowej aspekt nierówności został poszerzony o kryterium wieku, które nakreśla oczekiwania względem osób będących w konkretnym przedziale wiekowym. Można powiedzieć, iż status społeczny zmienia się w perspektywie cyklu życia. Dzieciństwo, wczesna młodość/młodość, dorosłość i starość są etapami, które doświadczają odmiennej oceny wartości i ważności, prowadząc do wystąpienia stereotypów i uprzedzeń względem osób w konkretnym wieku (Szukalski, 2004). Polaryzacja sposobu myślenia i traktowania jednostek i grup społecznych z uwagi na wiek definiowana jest jako dyskryminacja ze względu na wiek lub jako ageizm (Szukalski, 2015). Według Levy i Banaji ageizm to zmiana nastawienia w przestrzeni behawioralnej i emocjonalnej w stosunku osoby w danym wieku (Levy, Banaji, 2002, za: Świderska, 2015). Natomiast Szukalski określa ageizm jako „zestaw przekonań, uprzedzeń i stereotypów, mających swe podstawy w biologicznym zróżnicowaniu ludzi, związanym z procesem starzenia się, które dotyczą kompetencji i potrzeb osób w zależności od ich chronologicznego wieku” (2008, s. 144). Wiek metrykalny stanowi kryterium podziału grup, wobec których zostaje zastosowany system kontroli decydujący o dostępie do zasobów społecznych (Szukalski, 2008, s. 144).

W dobie kultu młodości śmiałym, a zarazem kontrowersyjnym zabiegiem może być postawienie pytania: Czy istnieje problem dyskryminacji dzieci i młodzieży? Obserwacja rzeczywistości oraz dyskurs naukowy pokazuje, iż pomimo medialnej promocji młodości równocześnie funkcjonują w kulturze i tradycji silnie zakorzenione przekonania pozycjonujące osoby młode na dole drabiny hierarchii społecznej. Dyskryminacji ze względu na wiek doświadczają nie tylko seniorzy, ale również osoby młode, czego odzwierciedleniem są brytyjskie badania z 2006 i 2007 roku, które pokazały, iż 43\% młodych Brytyjczyków doświadczyło dyskryminacji ze względu na wiek. Dla porównania dyskryminacji ze względu na płeć doświadczyło $27 \%$, z uwagi na rasę $11 \%$, zaś ze względu na orientację seksualną 6\% badanych. Badania te pokazały również, iż dyskryminacja ze względu na wiek postępuje wraz z kolejnymi etapami życia (doświadczyło jej 29\% dzieci poniżej 11. roku życia i aż 64\% adolesccentów) (Willow, Franklin \& Shaw, 2007, Gamelas, 2007, za: Liebel, 2017). 
W Polsce osoby w wieku 14-25 lat stanowią około 15\% społeczeństwa (GUS, 2017). Postrzeganie młodzieży jako grupy „innej” niekoniecznie stanowi problem sam w sobie. Staje się problemem, gdy domniemane różnice są wykorzystywane w celu wyjaśnienia, dlaczego grupa ta musi być traktowana w odmienny sposób niż inne grupy, nawet w sposób, który może im zaszkodzić (Czerepaniak-Walczak, 2010). Ponadto kreowanie obrazu młodzieży w oparciu o negatywne stereotypy może prowadzić do wzrostu niechęci, gniewu, lęku i niepokoju u starszych pokoleń.

W niniejszym tekście przytoczymy definicje adultyzmu oraz przedstawimy wyniki własnych badań na temat obszarów i form tego rodzaju dyskryminacji w percepcji młodzieży.

\section{PODSTAWY TEORETYCZNE BADAŃ}

Bliższe zaprezentowanie zagadnienia adultyzmu wymaga konceptualizacji pojęcia dyskryminacji. Termin ten pochodzi od łacińskiego discriminatio oznaczającego rozróżnienie. Według Allporta dyskryminacja rozumiana jest jako odmowa konkretnym jednostkom czy grupom społecznym równego traktowania, czego efektem jest usunięcie pewnych osób lub grup z określonych miejsc i sfer życia społecznego (Allport, 1979). Dyskryminacja może wiązać się ze zjawiskiem stygmatyzacji. Etymologicznie pojęcie stygmatyzacji wywodzi się z greckiego sigma, co oznacza piętno, znak, ślad. Goffman mianem piętna określa pewne atrybuty, cechy człowieka uznawane przez społeczeństwo za niewłaściwe, a wręcz dyskredytujące (Goffman, 2005). Napiętnowanie jednostki związane jest z odwołaniem się do jej negatywnego atrybutu i zdeprecjonowaniem stosownym do przyczepionej „łatki” (Kudlińska, 2011). Nadawanie negatywnych etykiet, deprecjonowanie jednostek często związane jest przypisaniem wartości i ról na podstawie niepełnych i niesprawdzonych informacji. Uleganie stereotypom i fobiom jest efektem lęku i niezrozumienia danego zjawiska czy grupy społecznej (Kosche, 2011). Łatwo znaleźć tutaj odzwierciedlenie w stosunku do dzieci i młodzieży, gdzie atrybut wieku przekłada się na postrzeganie ich jako gorszych i niepełnowartościowych członków społeczeństwa. Podstawą stygmatyzacji jest zawsze stereotypowe postrzeganie, czyli zestaw przekonań odnoszących się do różnych grup społecznych. Stereotyp definiowany jest jako konstrukcja myślowa łącząca w sobie komponent poznawczy, emocjonalny i behawioralny. To jednostronny, uproszczony i przerysowany obraz społeczności, który prowadzi do traktowania jej reprezentantów w jednakowy sposób, bez uwzględnienia ich indywidualności i różnorodności (Winiarska, Klaus, 2011). 
Kolejnym terminem powiązanym z dyskryminacją jest wykluczenie społeczne, czyli ekskluzja. Grotowska-Leder wskazuje na dwie perspektywy wykluczenia społecznego. Ujęcie partycypacyjne podkreśla ograniczenie udziału jednostki lub grupy w istotnych aspektach funkcjonowania społecznego - polityka, ekonomia. Natomiast ujęcie dystrybucyjne eksponuje ograniczenie dostępności do kluczowych zasobów społecznych - praca, świadczenia socjalne, służba zdrowia, edukacja czy konsumpcja (Grotowska-Leder, 2005, za: Kudlińska, Kacprzak, 2013). Wykluczenie społeczne jest pojęciem przeciwstawnym do społecznego uczestnictwa, to izolowanie jednostek, grup z szerszej zbiorowości, instytucji utrwalając podział „my” i „oni”. Wykluczenie społeczne jest procesem dotykającym coraz liczniejsze grupy (Giddens, 2004). Wśród grup zagrożonych wykluczeniem można niewątpliwie zaliczyć młodych ludzi, którzy przez proces stygmatyzacji napotykają na swej drodze coraz liczniejsze przeszkody ograniczające im pełne uczestnictwo w życiu społecznym (Maciaszek, 2012).

Dyskryminacja osób młodych ze względu na wiek jest formą ageizmu, która w literaturze przedmiotu funkcjonuje pod nazwą adultyzm. Zazwyczaj rozumiany jest jako nadużycie władzy, jaką dorośli mają nad dziećmi/młodzieżą (Flasher, 1978). To zachowania postawy oparte na przekonaniu, że dorośli są lepsi niż osoby młode, dlatego mogą podejmować decyzje bez konsultacji z nimi (Bell, 1995). Adultyzm jest koncepcją reprezentacji dorosłych jako lepszych przedstawicieli dziecka w aspektach antagonizmu władzy wobec podmiotów mniej dyskursywnych i podziału pomiędzy idealnym dorosłym a nieidealnym - dzieckiem’młodym (Amancio da Silva, 2014, s. 56).

Z pojęciem adultyzmu powiązane są następujące terminy:

- adultokracja - przewaga społeczna i polityczna oparta na autorytecie dorosłych (Dubanik, Kubacka, 2010);

- adultarchia - system władzy, w którym obowiązuje podział na dorosłych i młodzież. Można powiedzieć, iż jest to zestaw praw, praktyk i przekonań, które lokują władzę w rękach dorosłych. Osoby młode pozbawione są kontroli i możliwości podejmowania decyzji w kwestiach bezpośrednio ich dotyczących (Ostrowicka, 2011);

- adultcentryzm - punkt widzenia, w którym standardem i normą jest dorosłość, natomiast młodość postrzegana jest jako odchylenie od normy, stan przejściowy ku dorosłości, a wszelkie wynikające między nimi różnice traktowane są jako wady (Bonnichsen, 2011).

To zestaw praktyk, przekonań, praw, które w centrum stawiają człowieka dorosłego, postrzeganego jako stan idealny. Natomiast młodość traktowana jest jako stan przejściowy, pewien etap rozwojowy, postrzegany jako trud- 
ny i problematyczny, zarówno dla samej jednostki - jak i społeczeństwa (Ostrowicka, 2011);

- gerontokracja - skrajny przypadek adultyzmu, gdzie władza oligarchiczna skoncentrowana jest w rękach seniorów, czyli starszych od reszty populacji dorosłych (Dubanik, Kubacka, 2010, s. 138).

W literaturze naukowej można wyodrębnić następujące formy adultyzmu:

- adultyzm zinternalizowany - Chekoway twierdzi, że młodzi ludzie często sami kwestionują własne prawa, wątpią we własne możliwości, utrwalając tzw. kulturę milczenia (Chekoway 1996, s. 12). Przyczyn tego zjawiska należy upatrywać w procesie socjalizacji, w którym to dorośli przekazują informację dzieciom i młodzieży, że są mniej ważni i powinni się podporządkować woli rodziców. Różnorodne formy represji narzucane młodym ludziom przez dorosłych (kary, przemoc) przyczyniają się do zaakceptowania postaw nabytych w dzieciństwie i powielania ich w okresie własnej dorosłości.

- adultyzm instytucjonalny - systemowe uprzedzenia, w których formalne ograniczenia, wymogi, żądania są nakładane na jednostki ze względu na ich młody wiek. Prawo, polityka, struktury organizacyjne i procedury systemowe są mechanizmami wywierającymi wpływ, nacisk, utrwalając i wpajając adultyzmu w społeczeństwie - system kształcenia, dostęp do służby zdrowia, godzina policyjna (Liebel, 2017);

- adultyzm kulturowy - najczęściej występująca forma dyskryminacji. Każdy sposób ograniczenia czy wykorzystania ludzi ze względu na wiek określa się jako adultystyczny. Adultyzm jest pierwszym rodzajem dyskryminacji doświadczanym od wczesnego dzieciństwa (Fahrun, Skowron, Zimmermann, 2014). Dzieci/młodzież to jedna z najbardziej kontrolowanych grup w społeczeństwie. To dorośli decydują o wszystkich kwestiach dotyczących ich funkcjonowania (jedzenie, ubranie, sen, edukacja, znajomi, ścieżka życiowa). Nawet gdy zaczynają dorastać, opinie młodych ludzi rzadko są brane pod uwagę. Takie traktowanie dzieci młodych ludzi jest akceptowane ze względu na powielany model relacji młody-dorosły (Bell, 1995).

\section{METODOLOGIA BADAŃ WŁASNYCH}

Badania rozpoczęto od przeprowadzenia pilotażu z wykorzystaniem krótkiej ankiety zawierającej prośbę do respondentów o dokończenie zdań: Młodzi ludzie są...., Młodzi ludzie nie mogą... itp., a także wymienienie sytuacji, w których zo- 
stali potraktowani niesprawiedliwe ze względu na wiek. Inspiracją do badań były prace Delvina, Liebela i Young-Bruehl. Zdaniem tych autorów obraz młodzieży w dominujących dyskursach naukowych i medialnych jest niezaprzeczalnie negatywny, zarówno, jeśli chodzi o cechy osobowe młodzieży, jak i sytuacje, które ich dotyczą. Młodzież ukazuje się jako ludzi nie w pełni dojrzałych, gdzie wszelkie różnice rozumiane są jako deficyty (Bessant, 2012). Zdaniem Young-Bruehl dorośli posiadający władzę tworzą obraz młodych - gorszych równocześnie przypisując sobie pozytywne cechy (mądrość, racjonalność, siła), aby usankcjonować swoje postawy dyskryminacji i kontroli (Young-Bruehl, 2012, s. 38). Negatywne przekazy dotyczące młodzieży mogą mieć realny wpływ zarówno na relacje dorosłych z młodzieżą, jak i na doświadczanie młodości. W badaniach wykorzystano również typologię opracowaną przez Liebla (2017), która zakłada, że adultyzm może przybierać formy: kar za niepożądane zachowania u dzieci/młodzieży, które są tolerowane u dorosłych, rzekomą ochronę interesów dzieci i młodzieży, ograniczanie dostępu do dóbr, usług, instytucji oraz nieuwzględniania dzieci/młodzieży, jako grupy społecznej w procesie decyzyjnym. Badaniem tym objęto 30 osób celowo dobranych ze względu na wiek (18-20 lat) osób, a otrzymane wnioski posłużyły do stworzenia właściwego narzędzia w ramach strategii ilościowej.

W pierwszym etapie badań właściwych wykorzystano metodę sondażu diagnostycznego. Badania były przeprowadzone w grudniu i styczniu 2017/2018 roku. Grupę badaną stanowiła młodzież w wieku 18-24 lat (100 badanych). Przedział wiekowy został celowo rozszerzony, aby sprawdzić, czy przejawy dyskryminacji młodzieży zmniejszają się wraz z wkraczaniem w okres wczesnej dorosłości. Badani zostali dobrani w sposób celowy. Kryterium doboru respondentów stanowił wiek. W grupie objętej badaniem właściwym nie uczestniczyły osoby, które brały udział w badaniu pilotażowym. Grupa nie miała charakteru reprezentatywnego. Średnia wieku respondentów wyniosła 19,93 roku. Badana grupa składała się w 66\% z kobiet i w 34\% z mężczyzn. Rozkład badanych ze względu na miejsce zamieszkania wyglądał następująco: 25\% zamieszkuje tereny wiejskie, 10\% małe miasto, 28\% miasto średniej wielkości, zaś 36\% mieszka w dużym mieście. Celem tego etapu było przede wszystkim poznanie obszarów, w obrębie, których młodzi ludzie doświadczają dyskryminacji.

W drugim etapie badań, których celem było poznanie form adultyzmu, wykorzystano elementy metody Photovoice. W metodzie tej zakłada się, że badany występuje w roli eksperta w sprawie problemu, który go dotyczy (Niziołek, 2011), a wykorzystanie przez niego osobistych doświadczeń pozwala uchwycić to, co może być nieoczywiste dla badacza (Jarosz, Gierczyk, 2016). Zgodnie z założeniami w metodzie Photovoice grupa docelowa powinna składać się z siedmiu 
do dziesięciu osób (Wang 2006). Badani zostali dobrani ze względu na wiek, przy ich doborze zastosowano metodę kuli śnieżnej (Flick, 2010). Osoby biorące udział w tym etapie badań nie były objęte badaniem pilotażowym. Grupę badaną stanowiło 8 respondentów (6 kobiet i 2 mężczyzn) z terenu województwa śląskiego, mieszczących się w przedziale wiekowym 18-24 lat. Rozkład badanych ze względu na miejsce zamieszkania wyglądał następująco: 5 badanych mieszka w dużym mieście, 3 zamieszkuje miasto średniej wielkości. Po zapoznaniu badanych z celami badania i założeniami metody Photovoice zadaniem respondentów było wykonanie zdjęć na temat: W jaki sposób dyskryminowani są młodzi ludzie?. „W projektach Photovoice najważniejsza jest treść zdjęcia oraz emocje i doświadczenia, jakie chce nam pokazać fotograf. Nieodzowny jest podpis pod zdjęciem, dzięki któremu możemy lepiej zrozumieć sytuacje i uczucia autora (http://inkla.pl/ photovoice-3/)”. W związku z powyższym założeniem badani zostali poproszeni o opisanie zdjęć według wzoru:

- Nazwij swoje zdjęcie.

- Co się dzieje na Twoim zdjęciu?

Ponadto, respondenci zostali poinformowani o anonimowym wykorzystaniu fotografii w celach naukowych. Od badanych otrzymano łącznie 32 zdjęcia. Liczba fotografii wykonana przez jednego uczestnika wahała się od 2 do 5 sztuk. Pięć zdjęć zostało odrzuconych przez badaczki z powodu niezgodności z tematem badań - na fotografiach zawarte były motywy związane z dyskryminacją ze względu na płeć lub rasę. Dalszej analizie poddano 6 zdjęć z najczęściej pojawiającymi się motywami, na temat których poproszono badanych o wypowiedzenie się. W oryginalnej metodzie wybrane fotografie poddaje się dyskusji grupowej, jednak „Photovoice to niezwykle elastyczne narzędzie, które może być dopasowywane do sytuacji, możliwości, uczestników, miejsca oraz tematów” (Wójcik, Mondry, 2017, s. 95). Ze względu na fakt, że ten etap badań zbiegł się w czasie z okresem przerwy bożonarodzeniowej, dyskusję zastąpiono wywiadem pisemnym inspirowanym zdjęciami. Zaleca się, aby część związana z wywiadem występowała możliwie bezpośrednio po etapie wykonywania fotografii. Zapewnia to wyższe zaangażowanie badanych w projekt (Nykiforuk, 2011). Respondenci mieli za zadanie w oparciu o wysłane im zdjęcia udzielić odpowiedzi na następujące pytania (Jarosz, Gierczyk, 2016):

- Co widzicie na fotografii?

- W jaki sposób odnosi się to do was, do waszej codzienności? 
- Dlaczego ta sytuacja lub problem ma miejsce?

- Co Wam daje zrozumienie tej kwestii, jak nas to wzmacnia?

Dane w postaci tekstu, otrzymane z wywiadów, poddano kodowaniu otwartemu i selektywnemu (Konecki, 2008).

Badania zrealizowane sondażem diagnostycznym pozwolił nam poznać obszary i skalę dyskryminacji. Natomiast badania zrealizowane za pomocą metody Photovoice pozwoliły poznać formy doświadczeń dyskryminacyjnych.

Zwieńczeniem projektu było przygotowanie wraz z uczestnikami badania warsztatu dla młodzieży licealnej ma temat zjawiska adultyzmu i skutecznego radzenia sobie w sytuacjach dyskryminacji.

\section{REZULTATY BADAŃ WŁASNYCH}

Badania rozpoczęto od zapytania młodzieży, jaki jest ich zdaniem wizerunek młodego pokolenia w percepcji osób dorosłych.

$\mathrm{W}$ tym celu poproszono osoby uczestniczące $\mathrm{w}$ badaniu o wybranie trzech cech z zaproponowanej przez autorki listy przymiotników. Katalog przymiotników został opracowany w oparciu o badania pilotażowe. Badanych proszono o wymienienie pozytywnych i negatywnych cech, które ich zdaniem są najbardziej charakterystyczne dla współczesnej młodzieży. Wymienione przymiotniki zliczono, a cechy, które uzyskały najwyższą liczbę wskazań, posłużyły do utworzenia listy, która została wykorzystana w badaniu właściwym. Lista składała się z 6 cech pozytywnych (ambitni, aktywni, kreatywni, pełni energii, cieszący się życiem, realizujący pasje) oraz z 6 cech negatywnych (beztroscy, roztargnieni, niezdecydowani, skupiający się na byciu tu i teraz, agresywni, źle wychowani).

Zdaniem respondentów w obrazie młodzieży w percepcji dorosłych przeważają cechy negatywne. Najczęściej wskazywaną przez badanych cechą było określenie źle wychowani (62\%). Co drugi respondent jest zdania, że dorośli postrzegają młodych jako beztroskich (54\%), a co trzeci jako roztargnionych i skupiających się na „byciu tu i teraz” (35\%, 33\%). Z pozytywnych cech badani najczęściej wskazywali na określenie pełni energii (32\%). Najrzadziej respondenci wskazywali na takie cechy, jak m.in.: ambicja, realizowanie pasji, kreatywność, aktywność czy agresywność.

W literaturze przedmiotu podkreśla się dychotomiczny stosunek starszych pokoleń do młodzieży (Krupa, 2012). „Młodzież widziana oczyma dorosłych postrzegana jest jako »zagrożenie« i »wróg publiczny«” (Czerepaniak-Walczak, 
Cechy przypisywane przez dorosłych młodemu pokoleniu w percepcji badanych $(\mathrm{N}=100)$

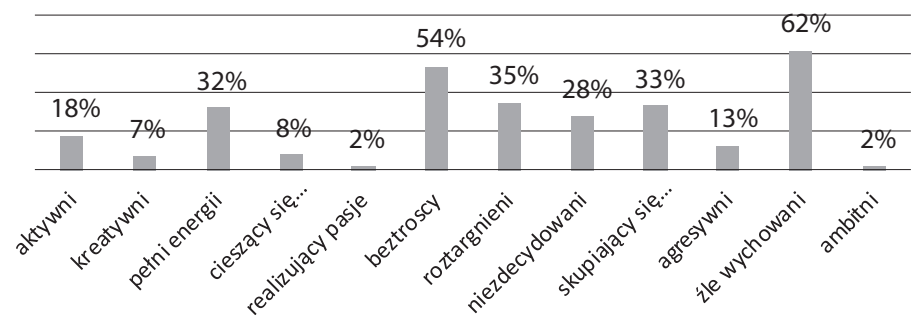

2010, s. 53). Jednocześnie podkreśla się ich pozytywne cechy: kreatywność i dynamizm. Zdaniem Małgorzaty Szcześniak i Glorii Randon młodzież od zawsze stanowi przedmiot zainteresowania i troski starszych pokoleń, które skłonne są tworzyć na temat tej grupy wiekowej wiele mitów i stereotypów (2011). Niestety w medialnym i publicznym dyskursie na temat młodzieży dominuje koncentracja na trudnościach i problemach, zagubiony zostaje natomiast obraz pozytywnego potencjału młodych (Grzelak i in., 2015). Odmitologizowanie młodości jest ważne kilku względów:

- negatywny obraz młodzieży kreowany przez dorosłych oraz negatywne postrzeganie siebie przez młodzież działa jak samospełniająca się przepowiednia (Grzelak i in., 2015);

- utrwalanie i powielanie negatywnych stereotypów może skutkować ograniczeniem krytycznego oglądu i rozumienia młodych przez starszych (Czerepaniak-Walczak, 2010), zaś przekonanie o negatywnym nastawieniu dorosłych może utrudniać nawiązanie dialogu ze starszymi pokoleniami przez młodzież;

- postrzeganie młodości jako najlepszego okresu w życiu utrudnia dostrzeganie łamania praw i problemów młodzieży.

Dobre relacje międzypokoleniowe - bazujące na szacunku i solidarności wymagają zatem wyzwolenia od opartego na powyższych schematach myślenia (Devlin, 2006).

Badani zapytani o to, w jakich sferach życia młodzi ludzie najbardziej doświadczają nierównego traktowania lub lekceważenia najczęściej wskazywali na sferę zawodową - nierówności w poziomie wynagrodzeń (44\%) oraz ograniczenia w dostępie do zatrudnienia (40\%). W dalszej kolejności wymieniano środowisko szkolne (33\%), rodzinne (31\%) oraz korzystanie z urzędów lub sposób traktowania w nich (28\%). Najrzadziej respondenci wskazywali na doświadczanie dyskrymi- 
nacji w takich obszarach, jak grupa koleżeńska (10\%) czy dostęp do dóbr i usług (15\%). Wyniki nie sumują się do 100\%, gdyż w pytaniu można było wskazać maksymalnie 3 sfery.

Główne obszary dyskryminacji młodych w opinii badanych

$(\mathrm{N}=100)$

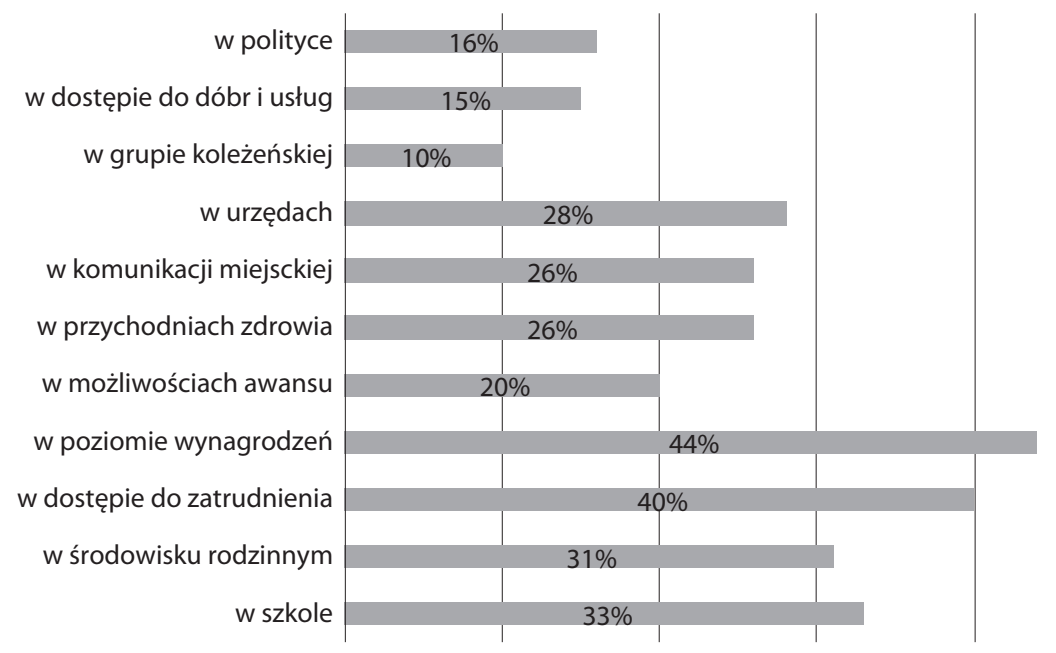

Interpretując wyniki, należy przypomnieć, że w Polsce osoby poniżej 25. roku życia tworzą bardzo liczną grupę osób pozostających bez pracy (Turska, 2000). Pomimo różnorodnych kwalifikacji (wyższego wykształcenia, znajomość języków obcych) młodzi mają trudność w wejściu na rynek, znalezieniu zatrudnienia lub pracują na niekorzystnych warunkach - na umowach śmieciowych z najniższym wynagrodzeniem. Ponadto wśród pracodawców istnieje tendencja do postrzegania młodzieży i młodych dorosłych jako grupy mniej niezawodnej, pracowitej czy chętnej do współpracy i mniej wykwalifikowanej niż osoby dorosłe. Oprócz uprzedzeń związanym z wiekiem preferencje pracodawców mogą być związane z płcią, rasą, pochodzeniem itp., co w konsekwencji powoduje, że młodzi w porównaniu z dorosłymi, są bardziej narażeni na bezrobocie (Drela, 2012). Dla porównania warto przytoczyć jeszcze wnioski z raportu przygotowanego na zlecenie Europejskiego Forum Młodzieży, który został opracowany w oparciu o badania przeprowadzone w 2014 roku na próbie 495 osób w wieku między 18 a 35 rokiem życia z całej Europy. Przedmiotem tych eksploracji była dyskryminacja wieloraka osób młodych. Wyniki badań pokazują, że młodzi ludzie doświadczają głównie dyskryminacji w następujących obszarach (European Youth Forum, 2014, s. 6): 
- 53,8\% respondentów doświadczyło dyskryminacji w obszarze edukacji;

- 50,5\% w poszukiwaniu pracy z wynagrodzeniem;

- 42,4\% w miejscu pracy;

- 29,2\% przy poszukiwaniu zakwaterowania;

- 26,6\% w opiece zdrowotnej.

Podobnie jak w przeprowadzonych przez nas badaniach najczęściej wymienianymi obszarami okazały się edukacja i zatrudnienie. W opisanych wyżej eksploracjach dyskryminacja ze względu na wiek występowała zarówno samodzielnie, jak i w połączeniu z innymi czynnikami, takimi jak płeć czy pochodzenie etniczne. Ponadto w badaniach zrealizowanych przez Gargouri i Guaman wśród młodych osób w wieku 18-29 lat, pokazały, że 30,77\% respondentów doświadcza dyskryminacji ze względu na wiek w miejscu pracy. Co ciekawe, młodzi ludzie objęci badaniami stwierdzili, iż czują, że ich współpracownicy mają skłonność do stereotypowego myślenia o nich, np. w kategoriach niedojrzałości i braku doświadczenia (60\%) (Gargouri, Guaman, 2017).

W obszarze edukacji dyskryminacja może mieć miejsce na dwóch poziomach: relacji rówieśniczych oraz relacji nauczyciel/wykładowca - uczeń/student. Nierówne traktowanie może przybierać formę poniżania, wyśmiewania, izolacji, odmawiania praw. Co istotne, wyniki badań nad zjawiskiem nierównego traktowania w środowisku szkolnym sygnalizują, że młodzież nie zna konstruktywnych sposobów reagowania na sytuacje dyskryminacji (Świerszcz, 2015).

Jak wynika z odpowiedzi badanych, o dyskryminacji można mówić także w ujęciu relacji najbliższych. W środowisku rodzinnym nierówne traktowanie jest związane z takimi zachowaniami, jak na przykład odmawianie współuczestniczenia w podejmowaniu decyzji związanych ze sposobem funkcjonowania rodziny (http:// www.siecrownosci.gov.pl/slownik-pojec/art,24,dyskryminacja-w-sferze-prywatnej. html).

\section{BADANIA Z WYKORZYSTANIEM ELEMENTÓW METODY PHOTOVOICE}

Na przedłożonych przez badanych zdjęciach postać pracodawcy, nauczyciela i relacji rodzinnych były często pojawiającym się motywem. Zdjęcia, które stały się podstawą wypowiedzi badanych zostały zawarte w aneksie. W tekście przytoczono fragmenty wypowiedzi badanych. Na końcu cytatu znajduje się sygnatura - oznacza ona numer przypisany badanemu.

Odnosząc się do sfery zawodowej, badani przytaczali sytuacje, kiedy młody wygląd lub wiek dyskredytował ich w procesie rekrutacyjnym. Niektórzy 
pracodawcy deklarowali wprost wolę zatrudnienia kogoś starszego, niezależnie od jego faktycznego doświadczenia, ponieważ taki pracownik wygląda bardziej profesjonalnie:

Gdy szukałam pracy, usłyszałam, że jestem za młoda. Mimo iż miałam najlepsze kompetencje, mogłabym obniżyć opinię firmy. (B6) ${ }^{4}$

Respondenci pisali o frustracji odczuwanej w związku z nierozpatrywaniem ich kandydatur (chociaż byli wyposażeni w odpowiednie kompetencje) lub oferowaniem im incydentalnego czy niezgodnego z wykształceniem zatrudnienia, co było niezgodne z ich ambicjami. Osoby, które posiadały już doświadczenie zawodowe, częściej skarżyły się na inną formę adultyzmu:

Mój były szef z czasem przestał prosić mnie o zrobienie mu herbaty. Po prostu stawiał przede mną pusty kubek i wychodził, oczekując, że gotowy napój przyniosę mu do gabinetu, chociaż nie należało to do moich obowiązków...

Oprócz wykonywania czynności niezwiązanych z zakresem obowiązków badani przytaczali także sytuacje, kiedy musieli usługiwać w pracy starszym kolegom.

Interesujące wnioski przyniosła analiza wypowiedzi na temat zdjęcia przedstawiającego dojrzałego mężczyznę o wyniosłej pozie na tle tablicy, na której widniały wzory matematyczne bądź chemiczne (aneks - zdjęcie 2). Wzbudziło ono w badanych skojarzenia z systemem edukacji, w której uczeń przyjmuje bierną i zależną pozycję:

Obraz ma na celu przedstawienie z perspektywy studenta wykładowcy, który poniża go, ponieważ jest w jego rozumieniu osobą niższego statusu społecznego (ze względu na wykształcenie), a także nie ma zbyt wystarczającej wiedzy, by wymieniać się z nim poglądami. (B1 - autor zdjęcia)

Jak pisałyśmy wyżej, dyskryminacja ze względu na wiek w sferze edukacji może dotyczyć relacji rówieśniczych (dyskryminacja przez starsze roczniki) oraz

\footnotetext{
${ }^{4}$ W tekście przytoczono fragmenty wypowiedzi badanych. Na końcu cytatu znajduje się sygnatura - oznacza ona numer przypisany badanemu.
} 
relacji nauczyciel/wykładowca - uczeń/student. Niestety ten drugi typ był przytaczany najczęściej np.:

Nauczycielka, znacznie ode mnie starsza, poddała w wątpliwość moją wiedzę tylko ze względu na mój wiek. (B8)

Wykładowca stawia siebie jako osobę kompetentną ponad wszystko, a zatem pozwala sobie na dyskryminacje studentów. (B1)

Badani skarżyli się na traktowanie ich z góry, postrzeganie nie jako aktywnych uczestników edukacji i współtwórców, ale wyłącznie jako biernych odbiorców treści edukacyjnych. Zdaniem respondentów takie postawy są uwarunkowane sposobem myślenia o młodych ludziach, przekonaniem o ich bezmyślności i niedojrzałości.

Natomiast adultyzm w sferze rodzinnej okazał się mieć miejsce we wszystkich typach relacji - z dziadkami, rodzicami, starszym rodzeństwem, a nawet starszym parterem/narzeczonym. Również w tym obszarze najwięcej zachowań związanych było przede wszystkim z podważaniem kompetencji, pojawiły się także wypowiedzi na temat wykluczania z możliwości współdecydowania w sprawach, które związane były z funkcjonowaniem badanych lub ich rodzin, np.:

Mój dziadek - chodź, pokażę ci, jak się gotuje zupę, bo na pewno nie umiesz. A umiem i śmiem twierdzić, że smaczniejszą niż dziadek. (B6)

Gdy nie byłam pełnoletnia, nie liczono się z moim zdaniem, bo traktowano mnie za dziecko. (B7)

Te i inne przykłady przytaczane przez badanych rodziły w nich gniew, bunt lub protest i pozostawiały przekonanie o byciu potraktowanym niesprawiedliwie. Jeden z badanych stworzył nawet żartobliwe określenie dla tego typu postaw dorosłych - „BSDM - brak szacunku do młodzieży”(B4).

Negatywny obraz młodzieży rozpropagowany w mediach czy opinii społecznej jest jednym z czynników przyczyniającym się do wzrostu izolacji i zmniejszenia wsparcia ze strony istotnych środowisk wychowawczych, które ograniczają młodym możliwości wpływania na otaczający świat. To systematyczne zaniedbanie jest wytworem społeczeństwa, które nie potrafi postrzegać młodzieży jako partnera, dać im siłę, by mogli mówić lub wpływać na ich własne życie (Abood, 2009). 


\section{KONKLUZJE}

Należy podkreślić, iż dorosłość jest szczególnie istotna dla młodzieży, która często znajduje się na samym końcu hierarchii społecznej. Dorośli powinni wspierać dzieci i młodzież w formalnych konsultacjach, umożliwiając im podejmowanie decyzji. Młodzi ludzie mają prawo do uczestniczenia i wyrażania swoich opinii, a dorośli mają obowiązek i możliwości niezbędne do wykonywania tych praw (Abood, 2009).

Można zmienić postrzeganie młodzieży poprzez tworzenie programów i angażowanie młodych w proces decyzyjny już na poziomie rodzinnym, edukacyjnym i lokalnym. Kluczem do rozwoju pozytywnych relacji między młodymi a dorosłymi jest prawidłowe uczestnictwo młodzieży w strukturach społecznych (Bell, 1995). Młodzi ludzie są siłą napędową pozytywnych zmian, mogą je kreować w swych środowiskach. Są kluczem do rozwiązywania wielu problemów. Ale ci młodzi ludzie nie działają w izolacji, bez wsparcia i zachęty. To współpraca dorosłych z młodymi odgrywa istotną rolę w kształtowaniu nowych relacji międzypokoleniowych i stanowi punkt wyjścia do właściwej polityki antydyskryminacyjnej młodego pokolenia.

\section{Bibliografia}

Abood, M. (2009). Beyond adult-centrism Advancing children's rights and well-being through participatory urban planning: A case study of Southeast Los Angeles. Pobrane z: https://www.oxy.edu/sites/default/files/imported/assets/UEP/Comps/2010/ Abood_Beyond\%20adult-centrism.pdf.

Allport, G.W. (1979). The Nature of Prejudice. London: Addison-Wesley Publishing Company.

Amancio da Silva, W. (2014). Literature children - child as a textual protagonist. International Journal of Elementary Education, 3(3), s. 54-57.

Bell, J. (1995). Understanding Adultism: A Major Obstacle to Developing Positive Youth-Adult Relationships. Somerville, MA: YouthBuild USA. Pobrane z: https://youthbuild. org/sites/youthbuild.org/files/kb_item/2011/11/792/UnderstandingAdultism.pdf.

Bessant, J. (2012). Seen But Not Heard: Age Prejudice and Young People. Pobrane z: http://thecannyoutlaw.com/features/original/2012/10/seen-but-not-heard-age-prejudiceand-young-people/.

Bonnichsen, S. (2011). Three Types of Youth Liberation: Youth Equality, Youth Power, Youth Culture. Pobrane z: http://www.youthrights.org/research/library/three-types-of-youth-liberation.

Chekoway, B. (1996). Adults as Allies. Partnerships/Community. Pobrane z: https://digitalcommons.unomaha.edu/slcepartnerships/38. 
Czerepaniak-Walczak, M. (2010). Zaskakujące, intrygujące, niezwyczajne obrazy młodzieży. Próba zastosowania koncepcji „Czarnych Łabędzi” w pedagogice młodzieży. Przegląd Pedagogiczny, 1(13), s. 52-64.

Devlin, M. (2006). Inequality and the stereotyping of young people. Report for The National Youth Council of Ireland and The Equality Authority. Dublin: The Equality Authority.

Drela, K. (2012). Dyskryminacja na polskim rynku pracy - aspekt młodzieży. Zeszyty Naukowe ZPSB Firma i Rynek, 1, s. 103-113.

Dubanik, J., Kubacka, J. (2010). Ageizm. W: M. Branki, D. Cieślikowska (red.), Edukacja antydyskryminacyjna. Podręcznik trenerski. (s. 136-142), Kraków: Villa Decius.

Fahrun, H., Skowron, E., Zimmermann, N-E. (2014). Diversity Dynamics: Activating the Potential of Diversity in Trainings A Handbook for Facilitators in Active Citizenship Education. Berlin: Deutsche Nationalbibliothek.

Flasher, J. (1978). Adultism, Adolescence. 13(51), s. 517-523.

Flick, U. (2010). Projektowanie badania jakościowego. Warszawa: Wydawnictwo Naukowe PWN.

Gamelas, C. (2007). “We are all equal and that's the truth.” Children and young people talk about age-discrimination and equality. London: Children's Rights Alliance for England. Pobrane z: http://www.crin.org/docs/CRAE_UK.pdf.

Gargouri, Ch., Guaman, C. (2017). Discriminating Against Millennials in the Workplace Analysis on Age Discrimination Against Young Adults. Journal of US-China Public Administration, 14(1), s. 38-45. DOI: 10.17265/1548-6591/2017.01.004.

Giddens, A. (2004). Socjologia. Tłum. A. Szulżycka. Warszawa: Wydawnictwo Naukowe PWN.

Główny Urząd Statystyczny (2017). Polska w liczbach. Warszawa: Zakład Wydawnictw Statystycznych. Pobrane z: https://stat.gov.pl/files/gfx/portalinformacyjny/pl/.../polska_w_liczbach_2017.pdf.

Goffman, E. (2005). Piętno: rozważania o zranionej tożsamości. Gdańsk: Gdańskie Wydawnictwo Psychologiczne.

Grotowska-Leder, J. (2005). Ekskluzja społeczna - aspekty teoretyczne i metodologiczne. W: J. Grotowska-Leder, K. Faliszek, (red.), Ekskluzja i inkluzja społeczna. Diagnoza-uwarunkowania-kierunki działań (s. 25-45). Toruń: Wydawnictwo Edukacyjne Akapit.

Grzelak, S. (red). (2015). Vademecum skutecznej profilaktyki problemów młodzieży. Przewodnik dla samorzqdowców i praktyków oparty na wynikach badań naukowych. Warszawa: Ośrodek Rozwoju Edukacji.

Dyskryminacja w sferze prywatnej. Słownik pojęć zwiq̨zanych z dyskryminacją. Pobrane z: http://www.siecrownosci.gov.pl/slownik-pojec/art,24,dyskryminacja-w-sferzeprywatnej.html.

Jarosz, E., Gierczyk, M. (2016). Photovoice w badaniach i działaniach społecznych. Pedagogika Społeczna, 2 (60), s. 167-181.

Kacprzak, A., Kudlińska, I. (2013). „Błędne koło”. Wykluczenie społeczne w biograficznym doświadczeniu biednych kobiet i trzeźwiejących alkoholików. W: A.M. Kłonkowska, M. Szulc (red.), Niewygodni, nienormalni, nieprzystosowani, nieadekwatni - społecznie wykluczeni (s. 251-266). Gdańsk: Wydawnictwo Uniwersytetu Gdańskiego. 
Konecki, K. (2008). Wizualna teoria ugruntowana. Rodziny kodowania wykorzystywane w analizie wizualnej, Przegląd Socjologii Jakościowej, 4 (3), s. 89-115.

Kosche, M. (2011). Ocena stygmatyzacji w świetle zasad życia społecznego. Seminare. Poszukiwania naukowe, 29, s. 123-136.

Krupa, B. (2012). Starość w percepcji młodzieży - perspektywa pedagogiczna, Nowiny Lekarskie, 81 (1), s. 36-43.

Kudlińska, I. (2011). Stygmatyzacja społeczna jako perspektywa teoretyczno-badawcza (na przykładzie badań nad stygmatyzacją ludzi biednych). Acta Universitatis Lodziensis Folia Sociologica, 38, s. 51-72.

Levy, B.R., Banaji, M.R. (2002). Implicit ageism, W: T.D. Nelson (ed.), Ageism. Stereotyping and prejudice against older persons (s. 49-75). London: MIT Press.

Liebel, M. (2017). Adultyzm i dyskryminacja wobec dzieci ze względu na wiek. W: U. Markowska-Manista, M. Liebel (red.), Prawa dziecka w kontekście międzykulturowości Janusz Korczak na nowo odczytany (s. 133-157). Warszawa: Wydawnictwo Akademii Pedagogiki Specjalnej.

Maciaszek, J. (2012). Pietno: problem stygmatyzacji i wykluczenia społecznego osób z zaburzeniami psychicznymi. Studia politicae Universitatis Silesiensis, 9, s. 299-315.

Multiple discrimination and young people in Europe (2014). Report and Survey commissioned by the European Youth Forum. Pobrane z: https://www.youthforum.org/ multiple-discrimination-and-young-people-europe.

Nizołek, K. (2011), Fotografia uczestnicząca. Od jakościowych badań światów społecznych do interwencji socjologicznej. Qualitative Sociology Review, VII, 1, s. 22-41.

Nykiforuk, C.I.J., Vallianatos, H., Nieuwendyk, L.M. (2011). Photovoice as a Method for Revealing Community Perceptions of the Built and Social Environment. International Journal of Qualitative Methods, 103-124. DOI 10.1177/160940691101000201.

Ostrowicka, H. (2011). Młodość jako kategoria i relacja w dyskursie edukacyjnym. Przegląd Pedagogiczny, 1(25), s. 277-284.

Projekt Inkla. Uniwersytet SWPS. Pobrane z: http://inkla.pl/photovoice-3/.

Szcześniak, M., Rondón, G. (2011). Pokolenie „ani-ani”: o młodzieży, która się nie uczy, nie pracuje i nie dba o samokształcenie. Psychologia Społeczna, 3(18), s. 241-251.

Szukalski, P. (2004). Uprzedzenia i dyskryminacja ze względu na wiek (Ageism) - Przyczyny, przejawy, konsekwencje. Polityka Społeczna, 2(359), s. 11-15.

Szukalski, P. (2008). Ageizm - dyskryminacja ze względu na wiek. W: J.K. Kowalewski, P. Szukalski (red.), Starzenie się ludności Polski - między demografiq a gerontologiq społecznq (s. 153-184). Łódź: Wydawnictwo Uniwersytetu Łódzkiego.

Szukalski, P. (2015). Dyskryminacja ze względu na wiek jako bariera jakości życia seniorów. Space - Society - Economy, 14, s. 11-23.

Świderska, M. (2015). Ageizm jako problem społeczny. Pedagogika Rodziny, 5(4), s. $41-50$.

Świerszcz, J. (2015). Dyskryminacja i edukacja antydyskryminacyjna w systemie edukacji formalnej. Wnioski z badań. Na podstawie prezentacji Małgorzaty Dymowskiej i Marty Rawłuszko, Towarzystwo Edukacji Antydyskryminacyjnej. W: Przeciwdziałanie dyskryminacji $w$ szkole i zapewnienie równego traktowania $w$ edukacji. Pobrane $\mathrm{z}$ : https://kph.org.pl/wp-content/uploads/2016/03/2015_Publ-pokonf_Rowna-Szkola.pdf. 
Turska, E. (2000). Od zabawy do pracy. Katowice: Wydawnictwo Naukowe Śląsk.

Wang, C. (2006), Youth Participation in Photovoice as a Strategy for Community Change. Journal of Community Practice, 14(1-2), s. 147-161.

Willow, C., Franklin, A., Shaw, C. (2007). Meeting the obligations of the Convention on the Rights of the Child in England: Children and young people's messages to Government. London: Children's Alliance for England \& National Children's Buereau.

Winiarska, A., Klaus, W. (2011). Dyskryminacja i nierówne traktowanie jako zjawisko społeczno-kulturowe. W: B. Kłos, J. Szymańczak (red.), Zasada równości i zasada niedyskryminacji, (s. 9-40). Warszawa: Biuro Analiz Sejmowych, Wydawnictwo Sejmowe Kancelarii Sejmu.

Wójcik, M., Mondry, M. (2017). Badania partycypacyjne z udziałem młodzieży. Projekt INKLA - zapobieganie przemocy rówieśniczej oraz projekt Photovoice - Szkoła, klasa, grupa rówieśnicza - blaski i cienie. Teraźniejszość - Człowiek - Edukacja , 20 (4), s. 85-102.

Young-Bruehl, E. (2012). Childism: Confronting Prejudice against Children. New Haven: Yale University Press.

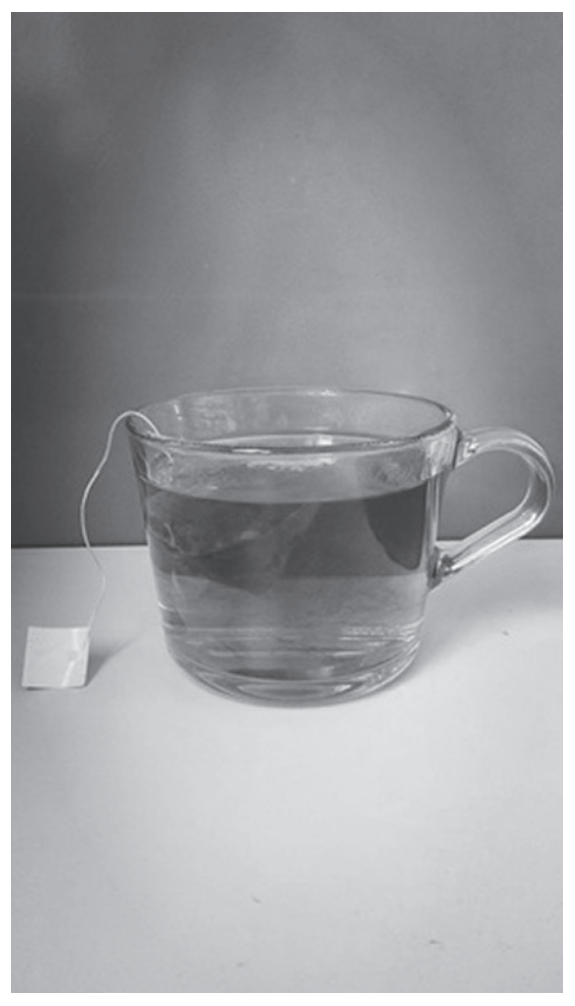

Zdjęcie 1. 


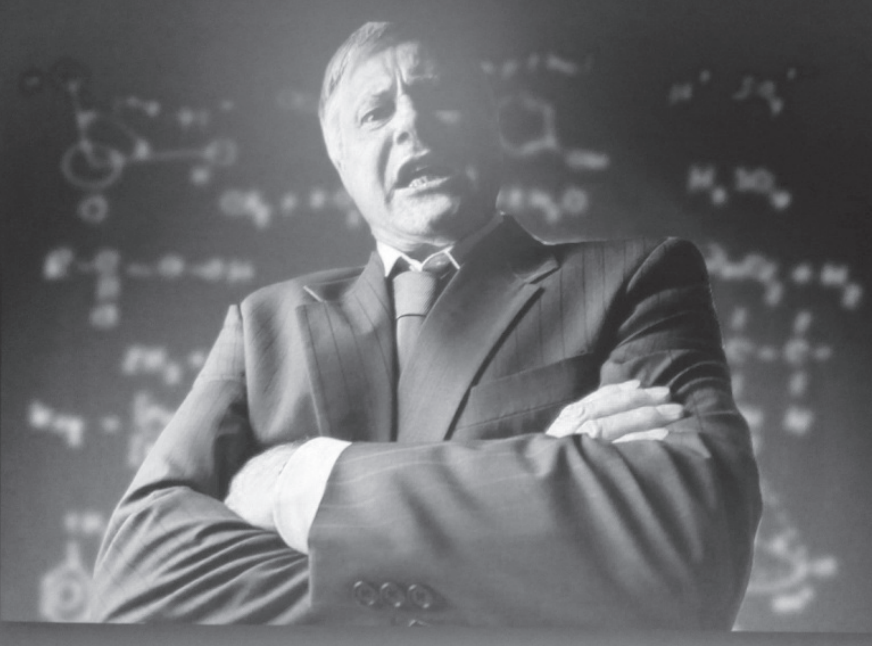

Zdjęcie 2.

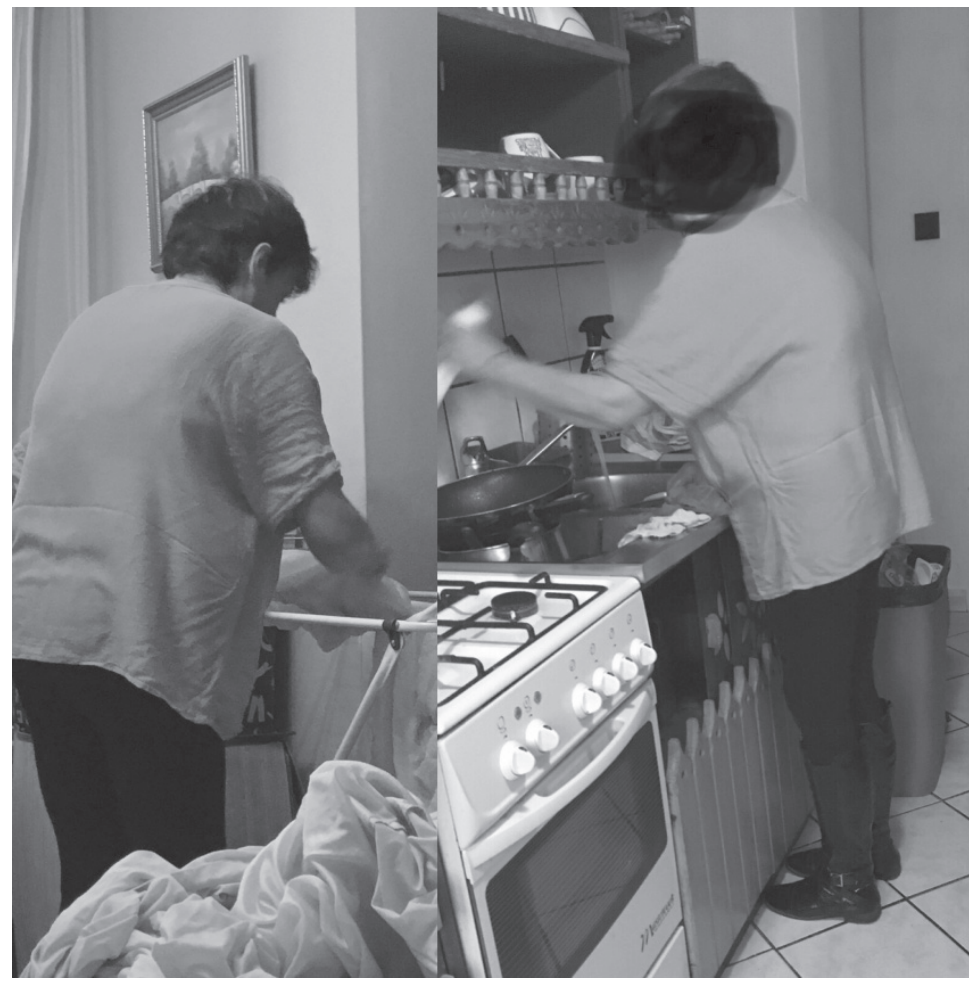

Zdjęcie 3. 